\title{
IT Governance Awareness and Practices: An Insight From Malaysian Senior Management Perspective
}

\author{
Yap May Lin, Noor Habibah Arshad, Halilah Haron and Yap Bee Wah \\ Universiti Teknologi MARA, Malaysia \\ Muhammad Yusoff \\ Open University Malaysia, Malaysia \\ Azlinah Mohamed \\ Universiti Teknologi MARA, Malaysia
}

\begin{abstract}
While corporate governance is now receiving due attention in the Asian region, IT governance (ITG) does not appear to be given much credence even though business processes today mandate IT. It is observed that awareness and practices of ITG do not seem to be widespread in the region. Using senior management sample data from Malaysian organizations, a study was conducted to determine the awareness and practices of ITG. Contrary to observation, findings indicated that Malaysian businesses appeared to exhibit awareness but ITG was only partially practiced. There was positive correlation between both concepts. Although the association was not causal, it revealed the potential tendency for awareness to cascade down to practices in an operating environment. ITG practices may be strengthened through senior management commitment and involvement, oversight committees, and real-world issues experienced by organizations such as the focus on IT creating tangible value to real stakeholders and the strategic alignment of IT to include the real business environment.
\end{abstract}

\section{Keywords}

IT Governance; Senior Management; Awareness; Practices

Copyright (C) 2010 Victoria University. This document has been published as part of the Journal of Business Systems, Governance and Ethics in both online and print formats. Educational and non-profit institutions are granted a nonexclusive licence to utilise this document in whole or in part for personal or classroom use without fee, provided that correct attribution and citation are made and this copyright statement is reproduced. Any other usage is prohibited without the express permission of the publisher.

\section{Introduction}

In line with the call for corporate governance addressed in the $9^{\text {th }}$ Malaysia Plan (or 9MP), transparency, accountability and disclosure are some of the issues that had been debated and publicized under the former prime minister's administration (EPU, 2006). Since the start of the millennium, some countries in the Asian region have either released corporate governance codes of practice or revealed their governance developments, such as the Singaporean Council on Corporate Disclosure and Governance released in August 2002 and the Malaysian Institute of Corporate Governance (MICG) which was established in March 1998 by the High Level Finance Committee on Corporate Governance with a mandate to raise awareness and practice of good corporate governance in Malaysia (Ho, 2005). In the case of the latter, the corporate reform was introduced to enhance the 
quality of good corporate management practice while addressing the weakness of corporate governance practices which became apparent during the Asian Financial Crisis in 1997 (Zainal Abidin and Ahmad, 2007).

However, there is little mention of information technology governance (or IT governance) even though these codes or developments assist organizations in the adoption of corporate governance. IT governance is one of the sub-sets of corporate governance as IT is considered as an integral component of any corporation or organization. Many definitions of IT governance exist but the commonly recognized ones include that of the IT Governance Institute (ITGI), the AS8015-2005 Australian Standard for Corporate Governance of Information and Communication Technology (ICT), and the definition provided by Weill and Ross (2004). IT governance is concerned about the deployment of IT resources in alignment with organizational strategies and objectives, the performance of IT in relation to value delivery and risk mitigation, and the conformance of IT processes to best practices (ITGI, 2003). A significant finding from the IT Governance Global Status Report 2003 (ITGI, 2004) indicated that IT governance implementation in Asia Pacific was the lowest compared to that of the rest of the world. Countries participating in this survey were Japan, Hong Kong, Indonesia, Australia and Singapore for the Asia Pacific region while the rest of the world was represented by the Americas and Europe. The awareness and practices of IT governance among businesses do not seem to be widespread in the Asia region although there are some media coverage and an increase in the number of conferences and workshops focusing on IT governance (Ho, 2005).

It is known that there are few studies done on IT governance in Malaysia (Noor Azizi Ismail, 2008; Suhaimi Ismail et al., 2007) and a seemingly lack of awareness studies on IT governance from the Malaysian perspective. Coupled with the attention drawn to corporate governance, addressed in RMK9, an insight into IT governance from Malaysian senior management perspective was deemed appropriate. Moreover, findings from a corporate governance study on a sample of Malaysian companies have revealed a positive association between the corporate governance practices and company performance (Ponnu, 2008). The likelihood of increased investor confidence with increased company performance from good corporate governance practices is reassuring. Similarly, increased IT performance through good IT governance practices will contribute significantly to the realization of IT investment with improved operational costs and client relationship, and business process efficiency gains (ITGI, 2003). The objective of this paper is to present empirical findings on the awareness and practices of IT governance among Malaysian businesses. In addition, findings on the association between the awareness and practices of IT governance are presented. These findings will contribute to the research base on IT governance and, from a Malaysian standpoint, provide an insight into the awareness and practices of governance, highlighting areas for improvement.

\section{IT Governance}

The purpose of IT governance is to direct IT endeavours to ensure that IT's performance meets the objectives set out in its strategy. Essentially, these objectives are the realization of promised benefits as a result of IT's alignment with that of the organization, the exploitation of opportunities and maximization of benefits from IT enabling the organization, the responsible use of IT resources, and the appropriate management of IT-related risks (Chalaris et al., 2005; ITGI, 2003). Senior management needs to be better assured that the organization's IT deliverables are met. Hence, the focus on the process by which an organization's IT is directed and controlled, therein lies the significance of IT governance. Furthermore, with effective governance, the return of IT investment will be high and this business investment in IT can be optimized to extend business strategies and goals. These claims are supported by studies from Weill and Ross (2004) and the IT Governance Global Status Reports (ITGI, 2006; ITGI, 2008).

In order for IT to be governed there must be recognition of the need for governance and a shift in the accountability for IT-related decision to the top of the organization. A review of literature on IT governance reflects a commonality in that IT governance is a top management concern (Johnson, 2005; Luftman et al., 2004; Read, 2004; Hardy, 2002). It is important that senior management has a working knowledge of the concepts and issues related to IT governance. An effective governance of IT is essential as IT significantly impacts an organization's business. This can be seen when IT 
delivers value to the organization by keeping IT initiatives aligned with the organization strategy and when risks are mitigated by establishing accountability and monitoring of IT performance (Read, 2004; ITGI, 2003).

Post literature on IT governance have focused on the domains of IT strategic alignment, IT resource management, risk management, performance measurement, and IT value delivery (refer to Table 1). These five domains have gained global recognition as accepted relevant domains of ITG as they are business-driven and align closely with the issues on which the board and executive management focus (Johnson, 2005). In addition, they represent five management-related issues associated with IT governance responsibilities (ITGI, 2003). To determine the awareness and practices of IT governance among local businesses, these domains were adopted for the study. Academic research regarding IT governance in Malaysia is very limited while most of the past research studies are international-based. Therefore, an examination into the awareness and practices aspects of IT governance was timely as the findings will provide an insight into the state of governance among Malaysian businesses from the perspective of senior management designees.

Table 1: Domain Description of IT Governance

\begin{tabular}{|l|l|l|}
\hline \multicolumn{1}{|c|}{ Domain } & \multicolumn{1}{|c|}{ Description } & \multicolumn{1}{c|}{ Reference } \\
\hline $\begin{array}{l}\text { IT strategic } \\
\text { alignment }\end{array}$ & $\begin{array}{l}\text { This domain focuses on ensuring the linkage of business } \\
\text { and IT governance plans, on defining, maintaining and } \\
\text { validating the IT value proposition, and on aligning IT } \\
\text { operations with enterprise operations. }\end{array}$ & $\begin{array}{l}\text { Buchta et al. (2007); } \\
\text { ITGI (2005a); Luftman } \\
\text { et al. (2004) }\end{array}$ \\
\hline $\begin{array}{l}\text { IT resource } \\
\text { management }\end{array}$ & $\begin{array}{l}\text { This domain focuses on key issues related to the } \\
\text { optimization of knowledge and infrastructure. It involves } \\
\text { the optimal investment in, and the proper management } \\
\text { of, critical IT resources (such as people, processes, } \\
\text { applications, infrastructure and information) to meet the } \\
\text { organizational strategic objectives. }\end{array}$ & $\begin{array}{l}\text { Beulen et al. (2006); } \\
\text { ITGI, 2005b; ITGI } \\
\text { (2003) }\end{array}$ \\
\hline $\begin{array}{l}\text { Risk } \\
\text { management }\end{array}$ & $\begin{array}{l}\text { This domain focuses on risk awareness by senior } \\
\text { management, a clear understanding of the organization's } \\
\text { ability to handle risk, transparency about the significant } \\
\text { risks to the enterprise, and embedding of risk } \\
\text { management responsibilities into the organization. }\end{array}$ & $\begin{array}{l}\text { ITGI (2005c); Luftman } \\
\text { et al., (2004); Hardy } \\
\text { (2002) }\end{array}$ \\
\hline $\begin{array}{l}\text { Performance } \\
\text { measurement }\end{array}$ & $\begin{array}{l}\text { This domain uses approaches, such as balanced } \\
\text { scorecards and maturity models, to track and monitor } \\
\text { strategy implementation, project completion, resource } \\
\text { usage, process performance and service delivery. }\end{array}$ & $\begin{array}{l}\text { ITGI (2005d); De Haes } \\
\text { and Van Grembergen } \\
\text { (2004) }\end{array}$ \\
\hline $\begin{array}{l}\text { IT value } \\
\text { delivery }\end{array}$ & $\begin{array}{l}\text { This domain is about executing the value proposition } \\
\text { throughout the delivery cycle, ensuring that IT delivers } \\
\text { the promised benefits against the strategy, concentrating } \\
\text { on optimizing costs and proving the intrinsic value of IT. }\end{array}$ & $\begin{array}{l}\text { ITGI (2005e); Hamaker } \\
\text { (2003); ITGI (2003) }\end{array}$ \\
\hline
\end{tabular}




\section{Research Methodology}

An empirical study was applied in this research using a questionnaire as the research instrument. Both primary and secondary data were used in order to achieve the objectives. The domains of IT governance were determined from previous research (refer to Table 1) and used to determine the awareness and practices of IT governance among Malaysian businesses. The content validity of the research instrument was established through feedback by practitioners with experience in the subject matter. Reliability tests were conducted on (i) a set of 20 awareness items and (ii) a set of 15 practices items in the questionnaire. The results showed high alpha readings $(\alpha>0.9)$ for both item sets, indicating that both sets of measured items were excellent. The contact details of 150 organizations were obtained via Web business directories. Convenience sampling was applied in the primary data collection using both electronic and postal mail. The target population was senior management personnel. Analysis of primary data was supported by the application of appropriate statistical techniques.

\section{Research Model}

A research model (Figure 1) was developed focusing on the awareness elements of IT governance. Endsley's situational awareness model (1995) was adopted for this research model. According to Endsley (1995), situational awareness (SA) is "the perception of elements in the environment within a volume of time and space, the comprehension of their meaning, and the projection of their status in the near future". This definition is widely accepted as it is applicable across multiple task domains. Although frequently used for studies related to the military (French and Hutchinson, 2002; Endsley, 1998), the SA model has applicability in complex systems like businesses that are supported by IT/information systems (Lee et al., 2003; Endsley, 2001). Understanding people's awareness of how to process and utilize information around them will aid in supporting the delivery of effective performances. Senior management should harness SA to ensure they make well-informed decisions leading to effective planning and accurate formulation of the organization's future goals (Miller, 2006; Resnick, 2003). Having an accurate understanding of the current situation is vital to business leadership decision-making. The impact of SA information has been found to have positive effects from the decisions made as a result of it (Lee et al., 2003). The research model was built based on the combination of several past literatures instead of a single research model. The model focused more on the process and proposed a three-level awareness concept of perception, comprehension, and projection. The application of awareness levels on the domains of IT governance was used to measure management's awareness and understanding of IT governance through the frequency at which the processes are conducted, from senior management's perspective.

Senior management gathers perceptual information from the operating environment and selectively attends to those elements that are most relevant for the task at hand. In the context of IT governance, some of the processes related to this level of awareness include risk management addressed by senior management, the availability of resources, infrastructure and skills to meet current tasks and organization strategic goals, the compliance with application regulations, the inclusion of IT in the board's agenda, and the communication of the business direction to which IT should be aligned. In addition, close monitoring is paid to IT investment value through pending and achieved tangible and intangible assets like improvements in client relationship, operational costs, business efficiency gains, and achieving organization's strategic goals.

At the comprehension level, senior management must be able to integrate incoming perceptual information with existing knowledge, revealing an understanding of the significance of these elements in the current context. Therefore, from the perspective of IT governance, comprehension from respondents can be derived from senior management's realization of the important role played by IT in the organization, and consequent regulated monitoring of IT for return-on-investment (ROI) and the frequency of decisions about IT usage made jointly by business and IT management. Senior management concerns also centre on the occurrence of risks and ways to mitigate them with arrangements for audits for independent assurances, while leveraging potential developments in IT for business growth and leveraging its knowledge to increase stakeholder value. 
The projection level of awareness is achieved when senior management is able to project the future actions of the elements in the operating environment by predicting and anticipating how incoming information will change the environment. To determine projection among the sample segment as it relates to IT governance, senior management must have addressed issues such as the management of assets in terms of suitable IT resources, infrastructures and skills to meet the organization strategic objectives, strategizing initiatives to manage the critical value of IT, striving for transparency in IT efforts and investments, ensuring the continuous support of the IT department on business user needs, and leveraging IT's potential contribution to business growth through participation in organizational change-setting and strategic direction.

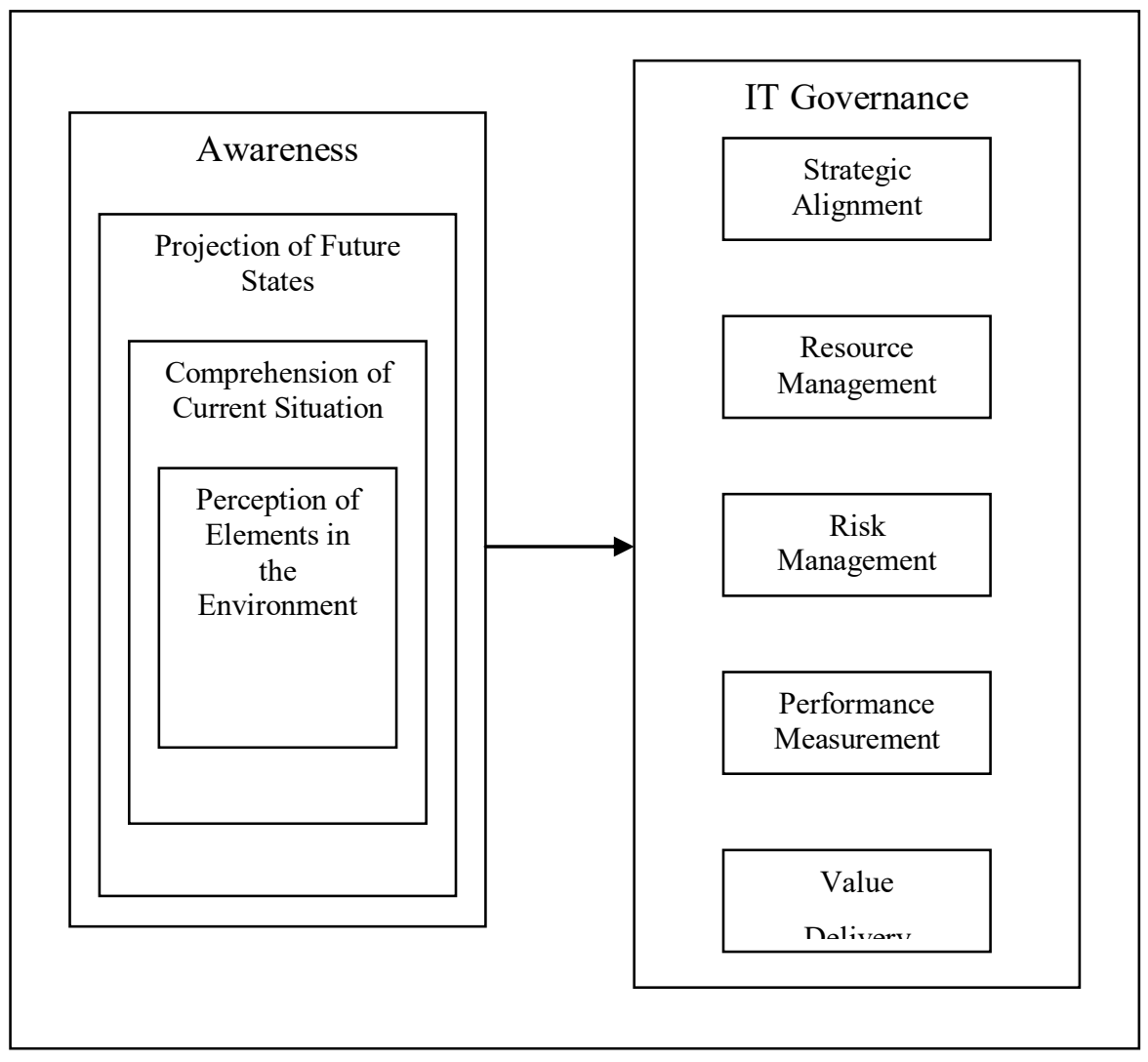

Figure 1: Research Model of the Awareness of IT Governance

The research hypotheses $\mathrm{H}_{1}$ to $\mathrm{H}_{15}$ that were formulated based on the research model in Figure 1 are listed in Table 2(i). The hypotheses were generated to test for positive associations between each awareness levels and each domain of IT governance. Each hypothesis has a null hypothesis that tested for no association. The hypothesis statement for $\mathrm{H}_{1}$ was written as follows:

$\mathrm{H}_{0}$ : There is no positive association between the awareness level of perception and the strategic alignment domain of IT governance.

$\mathrm{H}_{1}$ : There is a positive association between the awareness level of perception and the strategic alignment domain of IT governance.

Hypotheses $\mathrm{H}_{16}$ to $\mathrm{H}_{20}$ were generated to test for positive associations between the awareness construct and the domains of IT governance. The hypotheses are listed in Table 2(i). Each hypothesis has a null hypothesis that tested for no association. The statement for $\mathrm{H}_{16}$ was:

$\mathrm{H}_{0}$ : There is no positive association between the awareness construct and the strategic alignment domain of IT governance.

$\mathrm{H}_{16}$ : There is a positive association between the awareness construct and the strategic alignment domain of IT governance. 
Table 2(i): Research Hypotheses for Awareness of IT Governance

\begin{tabular}{|c|c|}
\hline $\mathrm{H}_{1}$ & $\begin{array}{l}\text { There is a positive association between the awareness level of perception and the strategic alignment domain of IT } \\
\text { governance. }\end{array}$ \\
\hline $\mathrm{H}_{2}$ & $\begin{array}{l}\text { There is a positive association between the awareness level of comprehension and the strategic alignment domain } \\
\text { of IT governance. }\end{array}$ \\
\hline $\mathrm{H}_{3}$ & $\begin{array}{l}\text { There is a positive association between the awareness level of projection and the strategic alignment domain of IT } \\
\text { governance. }\end{array}$ \\
\hline $\mathrm{H}_{4}$ & $\begin{array}{l}\text { There is a positive association between the awareness level of perception and the resource management domain of } \\
\text { IT governance. }\end{array}$ \\
\hline $\mathrm{H}_{5}$ & $\begin{array}{l}\text { There is a positive association between the awareness level of comprehension and the resource management } \\
\text { domain of IT governance. }\end{array}$ \\
\hline $\mathrm{H}_{6}$ & $\begin{array}{l}\text { There is a positive association between the awareness level of projection and the resource management domain of } \\
\text { IT governance. }\end{array}$ \\
\hline $\mathrm{H}_{7}$ & $\begin{array}{l}\text { There is a positive association between the awareness level of perception and the risk management domain of IT } \\
\text { governance. }\end{array}$ \\
\hline $\mathrm{H}_{8}$ & $\begin{array}{l}\text { There is a positive association between the awareness level of comprehension and the risk management domain of } \\
\text { IT governance. }\end{array}$ \\
\hline $\mathrm{H}_{9}$ & $\begin{array}{l}\text { There is a positive association between the awareness level of projection and the risk management domain of IT } \\
\text { governance. }\end{array}$ \\
\hline $\mathrm{H}_{10}$ & $\begin{array}{l}\text { There is a positive association between the awareness level of perception and the performance measurement } \\
\text { domain of IT governance. }\end{array}$ \\
\hline $\mathrm{H}_{11}$ & $\begin{array}{l}\text { There is a positive association between the awareness level of comprehension and the performance measurement } \\
\text { domain of IT governance. }\end{array}$ \\
\hline $\mathrm{H}_{12}$ & $\begin{array}{l}\text { There is a positive association between the awareness level of projection and the performance measurement } \\
\text { domain of IT governance. }\end{array}$ \\
\hline $\mathrm{H}_{13}$ & $\begin{array}{l}\text { There is a positive association between the awareness level of perception and the value delivery domain of IT } \\
\text { governance. }\end{array}$ \\
\hline $\mathrm{H}_{14}$ & $\begin{array}{l}\text { There is a positive association between the awareness level of comprehension and the value delivery domain of IT } \\
\text { governance. }\end{array}$ \\
\hline $\mathrm{H}_{15}$ & $\begin{array}{l}\text { There is a positive association between the awareness level of projection and the value delivery domain of IT } \\
\text { governance. }\end{array}$ \\
\hline $\mathrm{H}_{16}$ & $\begin{array}{l}\text { There is a positive association between the awareness construct and the strategic alignment domain of IT } \\
\text { governance. }\end{array}$ \\
\hline $\mathrm{H}_{17}$ & $\begin{array}{l}\text { There is a positive association between the awareness construct and the resource management domain of IT } \\
\text { governance. }\end{array}$ \\
\hline $\mathrm{H}_{18}$ & $\begin{array}{l}\text { There is a positive association between the awareness construct and the risk management domain of IT } \\
\text { governance. }\end{array}$ \\
\hline $\mathrm{H}_{19}$ & $\begin{array}{l}\text { There is a positive association between the awareness construct and the performance measurement domain of IT } \\
\text { governance. }\end{array}$ \\
\hline $\mathrm{H}_{20}$ & onstruct and the value delivery domain of IT governance. \\
\hline
\end{tabular}

To determine the practice of IT governance among Malaysian businesses, a research model, was developed based on past literature, as depicted in Figure 2. Practices in IT governance can be seen in planned and purposeful management processes such as reviewing the strategic role of IT and its alignment to organization objectives, monitoring potential conflicts between business and IT functions, enforcement of business continuity and security measures, and ensuring internal audit of IT processes. Senior management's involvement and support of IT governance can be seen from the frequency at which these processes were conducted. The application of practices on the domains of IT governance was used to measure management's practices of IT governance through the frequency at which the processes were conducted. The frequency of practice processes was based on senior management's perspective. 


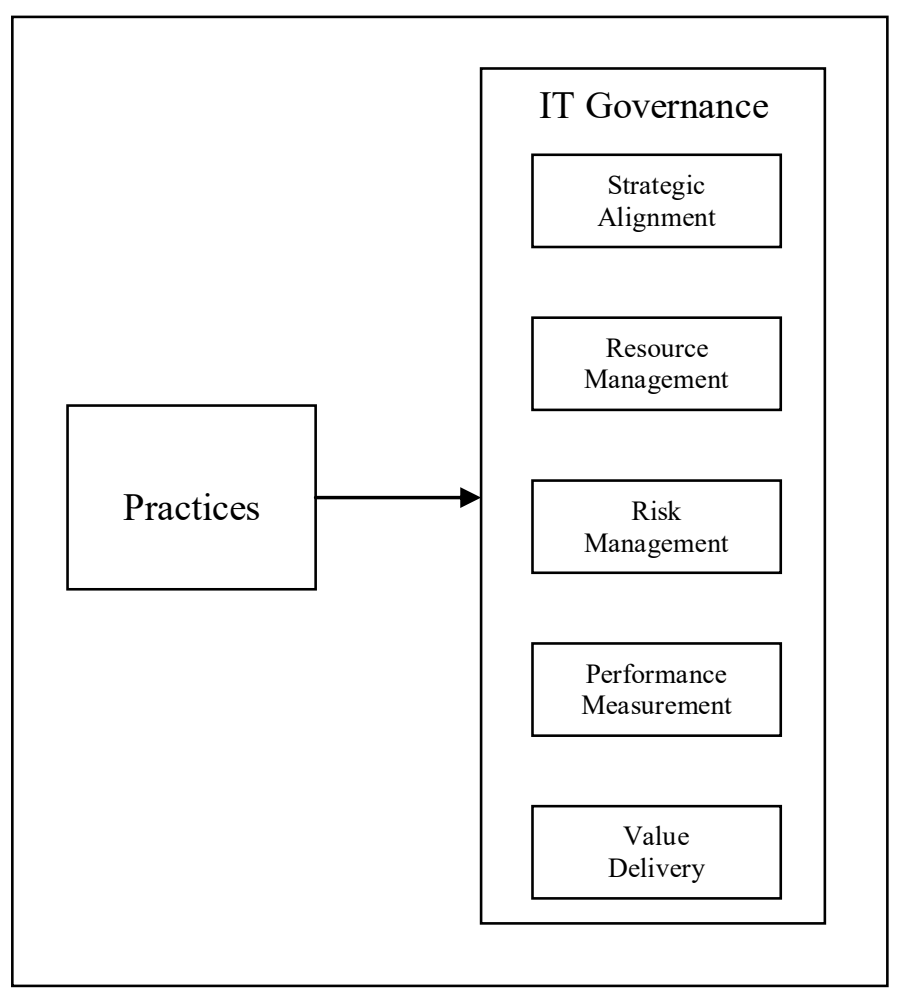

Figure 2: Research Model of the Practices of IT Governance

Research hypotheses $\mathrm{H}_{21}$ to $\mathrm{H}_{25}$ were formulated based on the research model in Figure 2 to test for positive associations between the practices construct and each domain of IT governance. The hypotheses are listed in Table 2(ii). Each hypothesis has a null hypothesis that tested for no association. The hypothesis statement for $\mathrm{H}_{21}$ was written as follows:

$\mathrm{H}_{0}$ : There is no positive association between the practices construct and the strategic alignment domain of IT governance.

$\mathrm{H}_{21}$ : There is a positive association between the practices construct and the strategic alignment domain of IT governance.

Table 2(ii): Research Hypotheses for the Practices of IT Governance

\begin{tabular}{|l|l|}
\hline $\mathrm{H}_{21}$ & $\begin{array}{l}\text { There is a positive association between the practices construct and the strategic alignment domain of IT } \\
\text { governance. }\end{array}$ \\
\hline $\mathrm{H}_{22}$ & $\begin{array}{l}\text { There is a positive association between the practices construct and the resource management domain of IT } \\
\text { governance. }\end{array}$ \\
\hline $\mathrm{H}_{23}$ & There is a positive association between the practices construct and the risk management domain of IT governance. \\
\hline $\mathrm{H}_{24}$ & $\begin{array}{l}\text { There is a positive association between the practices construct and the performance measurement domain of IT } \\
\text { governance. }\end{array}$ \\
\hline $\mathrm{H}_{25}$ & There is a positive association between the practices construct and the value delivery domain of IT governance. \\
\hline
\end{tabular}

Meanwhile, Figure 3 depicts a research framework of the association between IT governance awareness and practices. Correlation computation will determine the linear association between both awareness and practices concepts. 


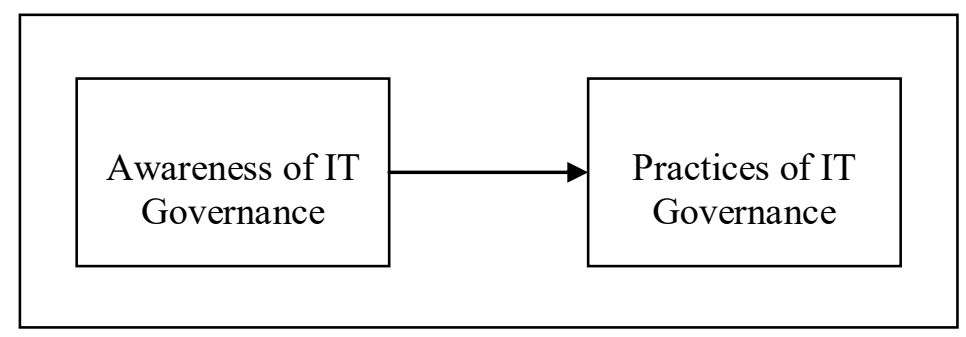

Figure 3: Research Framework of Association between IT Governance Awareness and Practices

Hypothesis $\mathrm{H}_{26}$ was generated to test for positive association between the awareness and practices concepts. Hypothesis $\mathrm{H}_{26}$ was stated as follows:

$\mathrm{H}_{0}$ : There is no positive association between the IT governance awareness construct and the IT governance practices construct.

$\mathrm{H}_{26}$ : There is a positive association between the IT governance awareness construct and the IT governance practices construct.

\section{Data Analysis \& Findings}

The survey captured background data of respondents' profile as well as their opinion on the awareness and practices of IT governance in their respective work environment. From the 150 sets of questionnaires that were distributed via convenience sampling, only 38 respondents answered, which amounted to an approximate $25 \%$ response rate. This rate is considered to be relatively normal (Scheaffer et al., 1996). The main reasons given for the lack of response were (i) company policy of not responding to surveys, and (ii) the nature of the study in question coupled with the level at which it was focused. The majority of the target respondents were located within the State of Selangor and the Federal Territories. They are essentially senior management designees such as members of the Board or C-suite (viz., Chief Executive Officer; Chief Information Officer; Chief Financial Officer; etc.).

\subsection{Demographic Profile}

The sample data comprised of members of the Board or C-suite (57.9\%) while the remaining (42.1\%) also hold senior management positions, such as senior managerial, executive, and advisory offices. As for the number of years the respondent has held the position, $36.9 \%$ of the respondents have reported to be in the current position for at least 6 years with $63.2 \%$ at less than 6 yrs. The majority of the respondents come from the private sector $(78.9 \%)$ followed by $21.1 \%$ from government-linked companies (GLCs), quasi government organizations, and Multimedia Supercorridor (MSC) status companies. $21.1 \%$ of the sample are from the IT (Consultancy/Services/Vendor) industry with $15.8 \%$ from the Banking and Finance industry. The remainder of the respondent organizations are from Retailing, Manufacturing (and Related Services), Telecommunications, Logistics, Engineering, and Construction industries. At least $50 \%$ of the respondents' organizations are medium to large in size. Most of the respondent organizations are quite matured with $73 \%$ being established for more than 10 years. Only $16 \%$ are operating for 5 years or less and cannot be excluded as some form of governance may be implemented at the onset of operations, but not formalized by name.

\subsection{Results of Factor Analysis}

To test the factorability of the sample data for awareness and practices, Bartlett's test of sphericity and the Kaiser-Meyer-Olkin (KMO) measure of sampling adequacy were conducted. The Bartlett test was found to be significant $(\mathrm{p}$-value $<0.05$ ) and the KMO measure was greater than 0.6 , thus, supporting factor analysis.

Factor analysis results from awareness data resulted in five valid factors of IT governance: strategic alignment, resource management, risk management, performance measurement, and value delivery. 
The reliability measures for the items of each factor were all above 0.7 , indicating that the internal consistency of the measured items was good. These factors were suspected to be the underlying domains from which the awareness of IT governance was determined. Using only valid factor loadings, the mean scores of awareness of IT governance were then computed (Table 3) using the sample mean statistic

$$
\bar{X}=\frac{1}{n} \sum_{i=1}^{n} X_{i}
$$

where $\mathrm{X}_{1}, \mathrm{X}_{2}, \ldots, \mathrm{X}_{\mathrm{n}}$ represent the sample size $\mathrm{n}$ and $\sum_{i=1}^{n} X_{i}$ denotes the sum of $\mathrm{X}_{1}+\mathrm{X}_{2}+\ldots+\mathrm{X}_{\mathrm{n}}$.

The rating scale used for the three levels of awareness was the 5-point Likert scale measuring frequency of occurrence $(1=$ Don't Know; $2=$ Not At All; $3=$ Seldom; $4=$ Frequent; $5=$ Always $)$. An observation made of the results was that there appeared to be a high potential frequency of awareness processes from the perspective of the respondents.

Table 3: Summary of Mean Scores of Awareness of IT Governance

\begin{tabular}{|l|c|c|c|}
\hline \multirow{2}{*}{\multicolumn{1}{|c|}{ IT Governance Domain }} & \multicolumn{3}{c|}{ Level of Awareness (Mean Score) } \\
\cline { 2 - 4 } & Perception & Comprehension & Projection \\
\hline Strategic Alignment & 3.747 & 3.794 & 3.758 \\
\hline Resource Management & 3.792 & 3.750 & 3.774 \\
\hline Risk Management & 3.846 & 3.780 & 3.706 \\
\hline Performance Measurement & 3.732 & 3.832 & 3.746 \\
\hline Value Delivery & 3.793 & 3.695 & 3.797 \\
\hline Mean (Overall) & $\mathbf{3 . 7 8 2}$ & $\mathbf{3 . 7 7 0}$ & $\mathbf{3 . 7 5 6}$ \\
\hline
\end{tabular}

In the perception level of awareness, the focus was on selectively attending to those elements of governance that were most relevant for the tasks at hand. The mean scores at the perception level of awareness were reasonably high with the overall mean of 3.782 indicating increasing occurrences of processes related to perceptual information on governance from the environment. The comprehension level enveloped perception of the governance domains present and included an understanding of the significance of these domains in the current context of the organization's goals. The overall mean of the comprehension level of awareness was 3.770, again indicating increasing occurrences of processes that pointed favourably toward an awareness of perception and with the integration of this perceptual information with existing knowledge, to understanding how it will impact upon the organization's objectives. Projection is the highest level of awareness, incorporating perception and comprehension, and was achieved when future actions related to the governance domains were projected in the respondent's working environment. The overall mean of 3.756 indicated that, from the respondents' perspective, there were increasing occurrences of processes related to the projection of IT governance domains. Hence, an extrapolation of the results of perception, comprehension and projection led positively to an awareness of IT governance in the operating environment of the respondents in the sample data.

Meanwhile, results of the factor analysis on the practices data indicated three valid factors of IT governance: risk management, performance measurement, and value delivery. The reliability measures for the items of each factor were all above 0.7 , indicating good internal consistency of the measured items. These factors were suspected to be the underlying domains from which the practices of IT governance were determined. A summary of the mean scores of practices of IT governance, derived from valid factor loadings, is depicted in Table 4. The mean scores for the strategic alignment and 
resource management domains were not calculated as these factors were deemed invalid with insufficient rotated factor loadings. However, this does not mean that strategic alignment and resource management practices do not exist entirely in the local business environment. It is quite likely that the sample size was relatively small and that there were low occurrences of processes related to the practice of both domains. Hence, factor analysis was not able to substantiate the validity of both factors.

Table 4: Summary of Mean Scores of Practices of IT Governance

\begin{tabular}{|l|c|}
\hline \multicolumn{1}{|c|}{ IT Governance Domain } & Mean Score \\
\hline Risk Management & 3.685 \\
\hline Performance Measurement & 3.697 \\
\hline Value Delivery & 3.658 \\
\hline Mean & $\mathbf{3 . 6 8 0}$ \\
\hline
\end{tabular}

The overall mean of 3.680 (Table 4) indicated that there was some level of practices of IT governance from the perspective of the respondents. The mean scores of the three governance domains were reasonably high indicating increasing occurrences of practices in these domains. However, the absence of validity for strategic alignment and resource management was indicative of the probable local perception towards IT governance practices, that is, the focus on assessing the returns on investment on client jobs with security investment factored in. There appeared to be room for improvement in governance practices while awareness of IT governance, from respondents' opinions, seemed to exist.

\subsection{Results of Correlation Analysis}

The Bivariate Pearson Product-Moment Correlation test was then administered on the research hypotheses generated for governance awareness (Table 2). The correlation coefficient $(r)$ was derived from the following statistic

$$
r=\frac{\sum x y}{\sqrt{\left.\left[\sum x^{2}\right) *\left(\sum y^{2}\right)\right]}}
$$

where the symbol $\sum$ denotes the "the sum of", $x=x_{i}-x$, where $x_{i}$ is the $x$ value for observation $i, x$ is the mean $x$ value, $y=y_{i}-y$, where $y_{i}$ is the $y$ value for observation $i$, and $y$ is the mean $y$ value.

The results of the hypotheses tests indicated strong and positive correlations for all 15 hypotheses that were tested (Table 5). The output also indicated that the associations between levels of awareness and the domains of IT governance are significant. Therefore, the higher the awareness levels, the higher the domain processes. 
Table 5: Results of Research Hypothesis Tests for Levels of Awareness of IT Governance

\begin{tabular}{|c|c|c|c|c|}
\hline Hypothesis & $\begin{array}{c}\text { Correlation } \\
\text { Coefficient }(r)\end{array}$ & p-value & Decision & Finding \\
\hline $\mathrm{H}_{1}$ & 0.932 & $0.000 *$ & Significant & Strong, positive association \\
\hline $\mathrm{H}_{2}$ & 0.911 & $0.000 *$ & Significant & Strong, positive association \\
\hline $\mathrm{H}_{3}$ & 0.952 & $0.000 *$ & Significant & Strong, positive association \\
\hline $\mathrm{H}_{4}$ & 0.950 & $0.000 *$ & Significant & Strong, positive association \\
\hline $\mathrm{H}_{5}$ & 0.947 & $0.000 *$ & Significant & Strong, positive association \\
\hline $\mathrm{H}_{6}$ & 0.969 & $0.000 *$ & Significant & Strong, positive association \\
\hline $\mathrm{H}_{7}$ & 0.967 & $0.000 *$ & Significant & Strong, positive association \\
\hline $\mathrm{H}_{8}$ & 0.943 & $0.000^{*}$ & Significant & Strong, positive association \\
\hline $\mathrm{H}_{9}$ & 0.943 & $0.000^{*}$ & Significant & Strong, positive association \\
\hline $\mathrm{H}_{10}$ & 0.955 & $0.000^{*}$ & Significant & Strong, positive association \\
\hline $\mathrm{H}_{11}$ & 0.928 & $0.000 *$ & Significant & Strong, positive association \\
\hline $\mathrm{H}_{12}$ & 0.914 & $0.000^{*}$ & Significant & Strong, positive association \\
\hline $\mathrm{H}_{13}$ & 0.956 & $0.000^{*}$ & Significant & Strong, positive association \\
\hline $\mathrm{H}_{14}$ & 0.957 & $0.000 *$ & Significant & Strong, positive association \\
\hline $\mathrm{H}_{15}$ & 0.951 & $0.000 *$ & Significant & Strong, positive association \\
\hline
\end{tabular}

* Significant at 0.10 level

Correlation tests were then conducted on research hypotheses $\mathrm{H}_{16}$ to $\mathrm{H}_{20}$ for positive associations between the awareness concept and the domains of IT governance. The results of the hypotheses tests (Table 6) indicated strong and positive correlations for all 5 hypotheses tested. In addition, there were also significant associations between the awareness concept and the governance domains. Consequently, an increase in the awareness concept will signify an increase in IT governance in the operating environment.

Table 6: Results of Hypothesis Tests for Awareness of IT Governance

\begin{tabular}{|c|c|c|c|l|}
\hline Hypothesis & $\begin{array}{c}\text { Correlation } \\
\text { Coefficient }(\boldsymbol{r})\end{array}$ & $\boldsymbol{p}$-value & Decision & \multicolumn{1}{|c|}{ Finding } \\
\hline $\mathrm{H}_{16}$ & 0.998 & $0.000^{*}$ & Significant & Strong, positive association \\
\hline $\mathrm{H}_{17}$ & 0.998 & $0.000^{*}$ & Significant & Strong, positive association \\
\hline $\mathrm{H}_{18}$ & 0.998 & $0.000^{*}$ & Significant & Strong, positive association \\
\hline $\mathrm{H}_{19}$ & 0.997 & $0.000^{*}$ & Significant & Strong, positive association \\
\hline $\mathrm{H}_{20}$ & 0.999 & $0.000^{*}$ & Significant & Strong, positive association \\
\hline
\end{tabular}

* Significant at 0.10 level

It was observed at this stage of the analysis that the management of Malaysian businesses appear to exhibit an awareness of IT governance from aspects of strategic alignment, resource management, risk management, performance measurement, and value delivery. As IT governance is a valuable subset of 
corporate governance, this is an interesting finding as it augers well for local businesses, especially with the call for corporate governance addressed in RMK9.

The Product-Moment Correlation test was administered on the research hypotheses generated on governance practices. Hypotheses $\mathrm{H}_{21}$ and $\mathrm{H}_{22}$ were not tested as they were found to be invalid after factor analysis. The results of the hypotheses tests, exhibited in Table 7, indicated strong and positive correlations for the 3 hypotheses tested. The output also indicated a significant association between the practices concept and three domains of IT governance. Consequently, the higher the practices concept, the higher the practices of risk management, performance measurement, and value delivery domains of IT governance in the operating environment.

Table 7: Results of Hypothesis Tests for Practices of IT Governance

\begin{tabular}{|c|c|c|c|c|}
\hline Hypothesis & $\begin{array}{c}\text { Correlation } \\
\text { Coefficient ( } \boldsymbol{r})\end{array}$ & $\boldsymbol{p}$-value & Decision & \multicolumn{1}{|c|}{ Finding } \\
\hline $\mathrm{H}_{23}$ & 0.949 & $0.000^{*}$ & Significant & Strong, positive association \\
\hline $\mathrm{H}_{24}$ & 0.946 & $0.000^{*}$ & Significant & Strong, positive association \\
\hline $\mathrm{H}_{25}$ & 0.909 & $0.000^{*}$ & Significant & Strong, positive association \\
\hline
\end{tabular}

* Significant at 0.10 level

While the results of Table 7 showed positive correlation between practices and three governance domains, the absence of the strategic alignment and resource management domains (very likely due to low occurrences and the relatively small sample size) posed the supposition that the concerns of the management of local businesses were more attuned to tangible benefits derived from IT investment in the here and now. Thus, in practice, having secured the company's IT with elements of risk management tools or techniques, the company's subsequent concern was that the IT performed to expectations. Forthwith, value was extracted when the IT projects were completed and delivered, and the customer indicated some measure of satisfaction. From the results of the data analysis in this section, it would seem that IT governance was only partially practiced by management of local businesses, in that specific governance domain practices were conducted more than others. Thus, as mentioned in Section 5.2, IT governance awareness was found to be present, judging from the opinions of the respondents, while there appeared to be room for improvement in the practices of IT governance as processes may be limited or under development, thus not used to their full capacity. This could have been attributed to the lack of expertise in the functionality of processes. In retrospect, it would seem that the general mindset of local businesses is attuned to the benefits of the technology as a commodity or support tool rather than as a strategic tool. According to a key observation in the IT Governance Global Status Report 2003, there is a tendency for IT to be looked upon more as a commodity in the Asia-Pacific region rather than as a means for gaining competitive advantage.

\section{Association between the Concepts of IT Governance Awareness and Practices}

With reference to Figure 3, the correlation test was administered on the hypothesis generated, and the result of the association between IT governance awareness and practices is shown in Table 8. The hypothesis was tested on the means of valid factor loading values of each concept.

Table 8: Results of Hypothesis Test of Association Between IT Governance Awareness and Practices

\begin{tabular}{|c|c|c|c|c|}
\hline Hypothesis & $\begin{array}{c}\text { Correlation } \\
\text { Coefficient (r) }\end{array}$ & p-value & Decision & Finding \\
\hline $\mathrm{H}_{26}$ & 0.811 & $0.000^{*}$ & Significant & Strong, positive association \\
\hline
\end{tabular}

The result of the hypothesis test indicated a significant, strong and positive association for hypothesis $\mathrm{H}_{26}$. Therefore, $\mathrm{H}_{26}$ was accepted and the null hypothesis was rejected. Thus, there exists the likelihood of increased awareness with increased practices of IT governance. The positive correlation between the IT governance awareness and the IT governance practices concepts were consistent with the rationale of the situation as an awareness of IT governance will lend itself to its practices in an 
organization. An interesting mention was reported in both the IT Governance Global Status Reports of 2003 and 2006 that a majority of respondents not only performed governance practices but had "hidden" governance implementations and did not characterize or label them by that name. In fact, some known IT governance frameworks, such as Control Objective for Information and related Technology (COBIT), Information Technology Infrastructure Library (ITIL), BS 7799-1/ISO/IEC 17799:2000 (Code of Practice for Information Security Management), and Capability Maturity Model Integration (CMMI) have been used by organizations for some time. It seems likely, therefore, that organizations with some semblance of governance or security awareness will inadvertently have either imbued some related governance processes into their regular work practices or incorporated a governance framework for compliance purposes. In fact, with the release of the ISO/IEC 38500:2008 Standard for Corporate Governance of IT (www.iso.org), organizations should do well to consider compliance with its guidelines in assisting top management to promote effective, efficient, and acceptable use of IT in the organization.

\section{Summary of Findings}

Thus, in summary, the findings in this study appear to support the general results of the IT Governance Global Status Report 2008 in terms of the governance awareness and practices. Global awareness of IT governance had increased with more respondents reporting that a number of ad hoc measures in place in their organizations to further awareness but there was a need for further improvement of governance practices (ITGI, 2009a; ITGI, 2008). The sample of senior management responses in this study exhibited the presence of awareness, through the application of the perception, comprehension, and projection levels of the situational awareness model on the five domains of governance. However, governance was only partially practiced, indicating the need for further improvements in this area with greater emphasis on governing and leveraging the technology strategically towards business growth.

\section{Conclusion \& Discussion}

This study provides an indication of what is happening to some local businesses based on the $25 \%$ response rate due to the nature of the study. Positive correlations were found between the awareness concept and the five domains of governance, while only three domains were found to be positively correlated to the practices concept. Moreover positive correlation was found between the awareness and practices concepts and although the association was not causal, it revealed the potential tendency for awareness to cascade down to practices in an operating environment. However, an issue of concern from the results of the study findings was why validity was not found for all domains in the IT governance practices concept of the study. With strategic alignment and resource management not being featured conspicuously in the findings, the possibility exists that although management was aware but in practice, other factors may contribute such that management may not have been able to successfully cascade the full capacity of all the governance domains into the operating environment to leverage the technology for business growth. This alludes to the perspective of most businesses in the Asia-Pacific region which looks upon the technology as a commodity or support tool rather than as a strategic tool to leverage and extend business strategies and goals (ITGI, 2004). Sustaining a business through tight economic times and an unstable global economy may not provide a suitable environment for companies to focus on instituting proper governance measures. Other factors may include pressures from technology, legal, politics, social, and environment that affect business activities, or simply the culture of the business that is only concern with what is expedient to achieving profits. IT governance practices may be improved by applying real-world issues experienced by organizations. The assimilation of such real experiences will strengthen IT governance implementation and work towards the continual improvement of its five domains by strategically aligning IT to include the real business environment, optimizing resources based on real business processes, improving real decisions by balancing risk and return, creating metrics based on real business-IT strategy alignment, and focusing on IT creating tangible value to real stakeholders (Barnier, 2010; ITGI, 2009b).

As IT governance is a sub-set of corporate governance, it is highly plausible that the strength of an IT governance initiative within an organization is identified through the strength of the overall corporate governance environment. Thus the commitment and involvement of senior management to set guiding principles, allocate clear roles and responsibility, and accountability for IT governance implementation 
and continual improvement within the organization is critical to its success (Weill and Ross, 2004; Read, 2004; ITGI, 2003). The establishment of relevant committee(s) comprising favourably of representation from senior, business, and IT management will provide the much needed mechanism for IT governance oversight and direction for improvement (ITGI, 2009b; Posthumusa and von Solms, 2005; Lientz and Larssen, 2004; De Haes and Van Grembergen, 2004; Hardy, 2003).

Future research may be conducted to identify contingencies that influence the practices of the governance domains. An issue of interest is an examination of the severity of IT-related problems within the operating environment and to test its associations with awareness and practices of IT governance. This research extension is currently underway and may provide further insights into IT governance implementation among Malaysian businesses.

\section{References}

Barnier, B. (2010). Five Tips to Take IT Governance to the Next Level. ISACA E-newsletter. January 20, 2010. (C) 2010 ISACA.

Beulen, E., Ribbers, P. and Roos, J. (2006). Managing IT Outsourcing: Governance in Global Partnerships. Routledge.

Buchta, D., Eul, M. \& Schulte, H. (2007). IT Planning - Integrating IT Planning into Corporate Planning. Book Chapter. Strategic IT Management: Increase Value, Control Performance, Reduce Costs. Gabler Verlag 2007. ISBN: 3834905577.

Chalaris, I., Lemos, P.P. and Chalaris, M. (2005). IT Governance: The Safe Way to Effective and Efficient Governance. E-Journal of Science and Technology. Vol. 1, Issue 1, pp. 59-63. ISSN 17905613.

De Haes, S. and Van Grembergen, W. (2004). IT Governance and Its Mechanisms The Information Systems Control Journal. Vol. 1.

Endsley, M.R. (1995). Measurement of Situation Awareness in Dynamic Systems. Human Factors. Vol. 37, No. 1, pp. 65-84.

Endsley, M.R. (1998). A Comparative Analysis of SAGAT and SART for Evaluations of Situation Awareness. Proceedings of the Human Factors and Ergonomics Society - 42nd Annual Meeting. Santa Monica, CA.

Endsley, M.R. (2001). Designing for Situation Awareness in Complex Systems. Proceedings of the $2^{\text {nd }}$ International Workshop on Symbiosis of Humans, Artifacts and Environment. Kyoto, Japan.

EPU (2006). Ninth Malaysian Plan (9MP): Blueprint of National Budget Allocation from 2006 to 2010. Prepared by the Economic Planning Unit (EPU) of the Prime Minister's Office and the Finance Ministry of Malaysia.

French, H.T. \& Hutchinson, A. (2002). Measurement of Situational Awareness in a C4ISR Experiment. Proceedings of the $7^{\text {th }}$ International Command and Control Research and Technology Symposium. CCRP: Washington, DC.

Hamaker, S. (2003). "Spotlight on Governance." The Information Systems Control Journal. Vol. 1.

Hardy, G. (2003). Coordinating IT Governance - A New Role for IT Strategy Committees. The Information Systems Control Journal. Vol. 4.

Hardy, G. (2002). Make Sure Management and IT are on the Same Page: Implementing an IT Governance Framework. The Information Systems Control Journal. Vol. 3.

Ho, J. (2005). IT Governance Regulation - An Asian Perspective. Information Systems Control Journal, Vol. 2, pp. 21-22.

ITGI (2003). Board Briefing on IT Governance. $2^{\text {nd }}$ Edition. IT Governance Institute. Available at http://www.itgi.org

ITGI (2004). IT Governance Global Status Report 2003. IT Governance Institute.

ITGI (2005a). IT Alignment: Who Is In Charge?. IT Governance Domain Practices and Competencies Series. IT Governance Institute.

ITGI (2005b). Governance of Outsourcing. IT Governance Domain Practices and Competencies Series. IT Governance Institute.

ITGI (2005c). Information Risks: Whose Business Are They?. IT Governance Domain Practices and Competencies Series. IT Governance Institute. 
ITGI (2005d). Measuring and Demonstrating The Value Of IT. IT Governance Domain Practices and Competencies Series. IT Governance Institute.

ITGI (2005e). Optimizing Value Creation From IT Investments. IT Governance Domain Practices and Competencies Series. IT Governance Institute.

ITGI (2006). IT Governance Global Status Report 2006. IT Governance Institute. Available at http://www.itgi.org

ITGI (2008). IT Governance Global Status Report 2008. IT Governance Institute. Available at http://www.itgi.org

ITGI (2009a). An Executive View of IT Governance. IT Governance Institute. Available at http://www.itgi.org

ITGI (2009b). Implementing and Continually Improving IT Governance. IT Governance Institute. Available at http://www.itgi.org

Johnson, E.C. (2005). IT Governance: New Players, Challenges and Opportunities. The Information Systems Control Journal. Vol. 2.

Lee, M-B., Suh, K-S \& Whang, J-H. (2003). The Impact of Situation Awareness Information on Consumer Attitudes in the Internet Shopping Mall. Electronic Commerce Research and Applications. Vol. 2, pp. 254-265. 2003 Elsevier B.V.

Lientz, B.P. \& Larssen, L. (2004). Manage IT as a Business: How to Achieve Alignment and Add Value to the Company. Elsevier Butterwoth-Heinemann.

Luftman, J.N., Bullen, C.V., Liao, D., Nash, E., \& Neumann, C. (2004). Managing the Information Technology Resource: Leadership in the Information Age. Pearson Prentice Hall, Inc.

Miller, A. (2006). Situational Awareness - From the Battlefield to the Corporation. Computer Fraud \& Security. Vol. 2006, Issue 9, pp.13-16. Sep 2006. Elsevier Ltd.

Noor Azizi Ismail (2008). Information Technology Governance, Funding and Structure: A Case Analysis of a Public University in Malaysia. Campus-Wide Information Systems. Vol. 25, No. 3, Pg. 145-160. Emerald Group Publishing Ltd.

Ponnu, C.H. (2008). Governance and Performance: Publicly Listed Companies in Malaysia. Journal of Business Systems, Governance and Ethics. Vol. 3, No. 1, pp. 35-53.

Posthumusa, S. \& von Solms, R. (2005). IT Oversight: An Important Function of Corporate Governance. Computer Fraud \& Security. June 2005.

Read, T.J. (2004) Discussion of Director Responsibility for IT Governance: A Perspective on Strategy. International Journal of Accounting Information Systems. Vol.5, pp. 105-107. 2004 Elsevier Inc.

Resnick, M.L. (2003). Situation Awareness Applications to Executive Dashboard Design. Proceedings of the Human Factors and Ergonomics Society - 47 $7^{\text {th }}$ Annual Meeting. October 13-17, 2003. Denver, Colorado.

Scheaffer, R.L., Mendenhall III, W. and Ott, A.L. (1996). Elementary Survey Sampling. $5^{\text {th }}$ Edition. Wadsworth Publishing Company. Duxbury Press.

Suhaimi Ismail, Rose Alinda Alias, Othman Ibrahim and Azizah Abdul Rahman. (2007). "An Integrated Framework for IT Governance in the Malaysian Ministry of Education." Postgraduate Annual Research Seminar (PARS'07). 3-4 July, 2007. UTM, Malaysia.

Weill, P. and Ross, J.W. (2004). IT Governance: How Top Performers Manage IT Decision Rights for Superior Results. Harvard Business School Press.

Zainal Abidin, N.A. and Ahmad, H.N. (2007). Corporate Governance in Malaysia: The Effect of Corporate Reforms and State Business Relation in Malaysia. Asian Academy of Management Journal. Vol. 12, No. 1, pp. 23-34. 
